The selection of subjects for study at the several seminars will seek to ensure that they will together cover a reasonably wide range of problems and methods, and that there will not be any undue overlapping of subject-matter and participants. Selection will also have regard to the interest and importance of a subject, both theoretical and practical, and its suitability for stimulating further research and, in particular, for promoting a greater exchange of views and information among scholars working in many different areas.

It is hoped to hold the first of these seminars at the East African Institute of Social Research, Makerere College, Uganda.

\title{
The Fifth Anniversary of the Ethnological Society of Addis Ababa
}

THE fifth anniversary of the Ethnological Society of Addis Ababa was celebrated on 7 July 1957, with a dinner, speeches, the reading of poems, and the distribution of prizes. Many messages of congratulation and encouragement were received from institutions and individuals, including Mr. Wolf Leslau, who emphasized that the society, in breaking through long-established taboos, was the first to deal with the scientific problems of its country and thus to be in direct touch with Western scholarship.

Mr. Assefa Liban, the President, paid tribute to the society's Adviser, Mr. Chojnacki, who is also the librarian of the University College, and who has spent much time and energy working for the preservation of the living traditions of Ethiopia. The society had been faced with three main difficulties: lack of interest in research work, lack of training, and lack of a transliteration system, but although progress had been slow there were now forty members trained in research.

Mr. Chojnacki stressed the point that the idea of research was a new one in Ethiopia; a start had been made with the subject most likely to stimulate the interest of Ethiopians, namely their own ethnology and their own past, and the field had proved to be rich and unexplored. The seventh Bulletin of the society contains ten articles of which two, 'Gada' and 'The commercial and agricultural documents of the Harari people in the nineteenth century', may be published as separate bulletins. Twenty-two members were offered new topics to work on during the vacation and three were working on Goğğam.

\section{World Health Organization Nutrition Training Course for English-speaking Countries in Africa South of the Sahara ${ }^{\mathrm{I}}$}

A NUTRITION course for doctors, veterinary surgeons, agronomists, educationists, and administrators was held in October and November 1957 in Kampala, Uganda, by invitation of the Government. The Director of the course was Dr. G. W. Gale, Professor of Preventive Medicine at Makerere College, where the meetings took place.

In his opening address, Dr. F. J. C. Cambournac, Regional Director of WHO in Africa, emphasized the paramount importance of improvement in the diet, and spoke of Africa as 'not so much an undernourished as a malnourished continent'. While the training of specialists was essential, their activities called for the support of all departments concerned in the raising of food-consumption levels, better utilization of existing resources, and education of the public.

The course was divided into two stages: the first stage was a five-week training course, consisting of lectures, demonstrations, field excursions, and discussions covering every aspect of human nutrition in Africa; the second stage was a one-week seminar, more particularly intended for officers holding high administrative positions, such as administrators, economists, and others from the level at which policies and programmes are discussed and decided.

" See Africa, xxviii. r, 1958, pp. 59-60. 